\author{
Jakub Petri \\ Department of Aesthetics, Faculty of Philosophy \\ Jagiellonian University, Kraków
}

\title{
TOUCHED BY A MURAL: SOMATIC ASPECTS OF URBAN PARTICIPATION
}

\begin{abstract}
The article covers the issue of somatic aspects of street art. The author discusses murals as a source of multi-sensual experience for citizens and also a medium of urban participation. Street art is being presented there as a sphere of dialogue between objectified and social sphere of urban life and private, embodied experience of citizens.
\end{abstract}

Keywords: murals, urbanity, participation, haptic sense, visuality

\section{Murals: visible objects or multi-sensual events?}

In times of extreme popularity of street art, not many people tend to ask what this jazz is all about. Do we really need all those oversized, eye-catching images covering walls of the ever-smaller cities worldwide?

One of the people who ask that is Halim Bensaid, the man behind dozens of mural projects in Western and Central Europe. Bensaid, co-founder of Cite Creation / DekorativeCity ensemble, seems to be in fact one of the few people curious whether apart from experiencing a "grand art market carnival" modern cities benefit from the street art craze. ${ }^{1}$ Bensaid seems to be highly critical in this area, thus he proposes to "reintroduce the debate on the fundamental and

1 CiteCreation / DekorativeCity, https://citecreation.fr/, http://dekorativecity.de/ [accessed: 7 August 2018]. 
essential concept of the relation of the citizen to his/her city". ${ }^{2}$ Meanwhile, the theme of the relation signalized by Bensaid appears in the modern aesthetic approach derived from the field of relational and environmental aesthetics. Murals, as a part of street art, are very commonly described as contextual and relational phenomena linked to the experience of urban daily life. ${ }^{3}$ However, in face of anesthetization provided by the overpresence of murals, the question if the mentioned perspective remains accurate seems to be important.

First, instead of being understood as relational and ephemeral, murals are very often presented with regard only to their visibility. This leads us to a certain narrative where murals are defined as networked images, lacking of their full somatic context. The multi-sensual, somatic context, however, seems to be fundamental for a full mural experience in real urban environment. From this point of view, there is something really alarming in modern mural tourism, based on the paradigm of urban visual culture, as murals, even broadly defined as urban events, tend to be understood and experienced only due to their pure visual aspects. ${ }^{4}$

Secondly, murals as phenomena of contextual and ephemeral nature should not be only considered as linked to their direct environment (locations), but also as to those who perceive them (visitors and passers-by). ${ }^{5}$ Such an expansion of research field would make it possible to explore the phenomenon in relation to the already mentioned multi-sensual perception model. On that occasion, it would

2 H. Bensaid, Mural Painting and The Spirit of The Place Versus Graffiti and Street Art, in: A. Gralińska-Toborek, W. Kazimierska-Jerzyk ed, Aesthetic Energy of the City. Experiencing Urban Art \& Space, WUŁ, Łódź, 2016, p. 156.

3 "Street art is a particularly contextually part of art as its very source derives from interacting with a city, a street, a wall or a passer-by. Moreover, these contexts are always changing. Official art of a public nature - architecture, monumental sculpture, urban design - is supposed to intentionally build the space in certain manner and is usually created in the space provided. Street art - on the contrary - is created where it is not expected, it changes the existing space in an unpredictable way and surprises. This change however, is usually not fundamental or permanent. [...] Street art is often called enironmental art. This work applies to a certain place, uses and changes this place and is closely linked to it". A. Gralińska Toborek, Street Art and Space, in: ed. A. Gralińska-Toborek, W. Kazimierska-Jerzyk, Aesthetic Energy of the City. Experiencing Urban Art \& Space, WUŁ, Łódź, 2016, pp: 85-89.

4 See Nicholas Mirzoeff's concept of "visual event" in which an aesthetic experience is provided through visual technology. N. Mirzoeff, An Introduction to Visual Culture, Routledge, London and New York 1999. In context of street art, it is important to mention the role of modern technology in mural experience (via smartphone applications, social media and videos). It is striking that one of the most important "beefs" (conflicts) between urban artists (King Robbo vs Banksy, 2013) was mainly experienced and commented in social media, while only a handful people physically entered Camden canals to experience the original artworks. For further reading: J.Petri, The Artisitic Turn in Graffiti Practice: Szwedzki vs Mona Tusz, Art Inquiry. Recherches sur les Art, XVII (XVI), 2015, pp. 371-387.

5 Expressions such as "viewers" or "spectators" are intentionally avoided in this article as they strengthen the problematic discourse on murals founded on the domination of a visual perspective. 
be reasonable however, not only just refer to multiplicity of senses (especially in their active modes) but also to take under consideration some passive experiences of tactile nature, caused by murals. This is necessary, as by their composition, scale and relation with buildings, murals affect not only our eyes, but appeal to the haptic sense of our bodies. ${ }^{6}$

In addition to the fact that on the already mentioned basic level, all murals can be understood as related to citizens bodies, some of them seem to be (or explicite are) designed to integrate embodied bystanders into specific forms of perceptual games. ${ }^{7}$

\section{Active and passive touch in urban environment}

To provide better understanding for the already mentioned process of somatic participation in a mural artwork I would like to analyze the relation between senses and the scale of the perceived structure. Jan Gehl, researching the quality of a desired urban space, mentions the importance of the relations of the scale, speed and intensity of sensual impulses. ${ }^{8} \mathrm{He}$ cites in this context the critical distance of 35 meters, which psychologists and anthropologists believe to be crucial for a specific sensual transition, when subject switches the mode of his/her perception from the process of projecting movement of the body (based on distant senses) to an emotional mode, which is also integrating more forms of human sensuality. ${ }^{9}$ Gehl appeals on this occasion to a classic

6 See J. Pallasmaa, Krajobrazy Zmystów. Dotykanie świata przez architekturę, in: Autoportret, 3 [35] 2011, pp. 5-11. According to Pallasmaa, contrary to common belief that architecture was and still is performed as a visual discipline, landscapes and buildings are in fact experienced in whole spectrum of senses. What is more, a passive sense of touch of unconscious nature is present in the sense of sight.

7 One of such examples is a long, horizontal work arranged by Silesian street artist Mona Tusz, on a wall of defunct coal mine in Siemianowice Śląskie (Park Tradycji). The mural depicting process of manufacturing or selecting goods on a production line, incorporates elements of a glass mosaic, which create mirroring areas, reflecting profiles of passers-by. The green, floral areas are designed as a part of the project, to create a kind of horizontal, relational space, which helps to perceive objects and people nearby as an immanent part of the mural. Organic, fragrant structures such as trees and carefully cultivated grass are confronted with synthetic or raw materials, but still being aspects of the same arrangement. The experience of the Mona Tusz creation, is one of a kind as thanks to the mentioned spatial strategies the mural acts not as a typical 2D image put on a flat wall but allows for some form of a multisensual immersion. http://www.monatusz.art.pl/index.php?/ongoing/park-tradycji/ accesed: 12.08.2018 See more in J.Petri, The Artistic Turn in Graffiti Practice: Szwedzki vs Mona Tusz, Art Inquiry. Recherches sur les Art, XVII (XVI), 2015, pp. 371-387.

8 J. Gehl, Zmysty i skala, in: Miasta dla Ludzi, Kraków, 2017 pp. 33-46.

9 Gehl gives an example of building strategies for operas and theaters all around the world, where the greater distance between the stage and the audience is precisely 35 meters, to provide people in further rows a chance of emotional engagement in the spectacle (which depends on their ability to read actors' facial expressions). J. Gehl, op cit, p. 37. 
division of senses made by Edward Hall in his books "The Hidden Dimension" and "The Silent Language". ${ }^{10}$ Gehl points out Hall's idea of the evolutionary division between sight, hearing and smell (distance senses) and feel and taste (close senses) as important also in modern urban experience. Gehl repeats there also Hall's notes on relationship between close senses and haptic qualities of human bodies, which are determined by skin, muscles and nervous system. The sense of feel (active and passive touch, balance) is extremely important in urban surrounding, as contrary to an already mentioned, specific arrangement of cultural institutions (such as operas and theaters), being immersed in urban space, a human being is intentionally and unintentionally confronted with plenty of impulses of haptic nature. However, one can notice that in practice of urban living, not only close senses are engaged by haptic feelings. It was yet Plato who in Timaios described a positive influence of haptic feelings originating from the movement of bodies in space, caused from the inside but also the outside (the journey on a boat, a vehicle) of the subject. ${ }^{11}$ Thus, also the experience of movement of one's body in space (speed) redirects itself to a haptic sphere of human experience.

It is important to note that active and passive touch seems to appeal as a medium that regulates proportions of the urban experience. It determines the level of participation, the range of connection to the structure of the city and, finally, the quality of the urban space. Gehl arguments there for, "slow spaces", as only the architecture which he calls the " $5 \mathrm{~km} / \mathrm{h}$ architecture" provides, in his opinion, the desired richness of sensual impulses. ${ }^{12}$ This type of architecture should be determined by small spaces, small distances and complicated structure of buildings and limited to walking experience only (even bike rides faster than $5 \mathrm{~km} / \mathrm{h}$ ). Finally, the desired space should be the horizontal as it should appeal to human horizontal somatic setup.

As I will argue further, the already mentioned conditions are fulfilled perfectly by contextual murals. However now, it is important to note why murals, instead of many proofs coming from daily life experience, are neither so widely researched as contextual and nor perceived as source of multi-sensual joy for citizens on a field of aesthetics and art critic. Paradoxically, as it was stated before, modern environmental aesthetics seems to provide keys to describe street murals as objects/events integrated in participatory model of urban environ-

10 E. Hall, The Hidden Dimension, New York, 1990, E. Hall, The Silent Language, New York, 1973

11 See J.Petri, Body Consciousness in Urban Surrounding: Freerunning and Parkour, in: A. Gralińska-Toborek, W. Kazimierska-Jerzyk ed, Aesthetic Energy of the City. Experiencing Urban Art \& Space, WUŁ, Łódź, 2016, pp. 131-141.

12 J. Gehl, op cit, p. 44. 
ment. Aleksandra Łukaszewicz - Alcaraz applies Arnold Berleant's concept of participatory model of environmental embodied perception to her analysis of murals, graffiti and vandalism in urban environment, where she describes them in accordance with the general division between psychological and contextual field of perception proposed by Berleant. ${ }^{13}$ Surprisingly, she divides murals and graffiti into two distinct categories, where graffiti is examined as a contextual, embodied practice, while street art as "psychological", non-contextual, and meant to fit into the traditional model of visual perception (subject vs. object of visual perception). ${ }^{14}$ The division creates some further problematic consequences, as according to Berleant's theory murals should be regarded as non-transforming, which ultimately poses an important question: why do we try to transform urban spaces worldwide, using non-transforming tools? The question of course is absurd, as people generally tend to think that murals (better or worse) do work, what means that they somehow transform urban spaces and change their quality.

Therefore, how to explain the discrepancy between citizens' expectations from their daily life experience and the voices of art critics and aestheticians? First, it seems obvious that most theoreticians tend not to perceive street art as a practice that has organically developed in urban surroundings, but rather as a form of enhancement of art strategies, applied by professional artists outside of traditional art galleries. Secondly, in the mentioned discourse, street art is mainly considered as an activity undertaken in urban surrounding, and is rarely being described in its passive aspect, from the level of a certain structure, which is generating various contexts for citizens. Meanwhile, street art seems to be a broader phenomenon and some others tools should be applied to reveal more aspects of it. To explain this postulate, we should take a look at street art practice of Mona Tusz, Polish urban artist, author of the afore-mentioned "Mosaic mural" in Siemianowice Śląskie. Unlike many street artists, Mona is formally educated (she is also a painter and a photographer), but as many other street creators, she makes many official, commissioned projects. In spite of the latter, it would be very risky, however, to frame her actions as purely visual and decorative. She does not act as a painter, simply using walls as canvas, quite the opposite, she defines her activity as a kind of urban animation project, which

13 "Generalizing the participatory model of environmental perception, the body as an organic, social, conscious organism is understood as a material node that is both the generator and the product of environmental forces" A. Berleant, Aesthetics and Environment. Theme and Variations on Art and Culture, Aldershot - Burlington: Ashgate, 2005, p. 23.

14 A. Łukaszewicz - Alcaraz, Street-art, graffiti, wandalizm - w kontekście estetyki środowiskowej Arnolda Berleanta, in: M. Baranowski, P. Cichocki, Przestrzeń publiczna i państwo dobrobytu, UAM, Poznań, 2016 pp. 13-28. 
should bring benefits to local communities in postindustrial region of Silesia. ${ }^{15}$ Her works are therefore intended as participatory and contextual. In addition to this, many of her murals, including the "Mosaic" one, are obviously planned as structures to be somatically explored by citizens, thus something much more than just a fancy image made for a decorative purpose. ${ }^{16}$

\section{How does a mural work then?}

Taking under consideration the above remarks, it is important to note that some street artists intentionally project their mural works as a specifically arranged spaces of somatic participation. Such mural is gaining a regulative character as it attracts and redirects the flow of human bodies in the urban space. It seems the manner of existence of such a structure in urban context can be understood as an 'in-between', transitory space, that is stretched somewhere in spectrum between the idealized (visual) and anarchic models of urbanity.

The first extreme, a visual model of urban space, identified according to a popular book by Kevin Lynch entitled "The Image of the City", has been widely criticized in the name of the somatic turn in urban planning. It seems, however, that the above-mentioned, still popular concept of murals as purely visual and decorative (due to their subversion of the visual urban planning policy) can be understood as a leftover of Lynch's abandoned concept. ${ }^{17}$

Referring to the other side of the spectrum, defined by anarchic, temporary spaces, another problem occurs, as anarchy, with its radical informality (which in urban context is broadly associated with graffiti) does not provide a sufficient comfort zone for citizens. Graffiti is then often described as a medium of symbolic violence and a kind of secret professional language that appropriates urban space and excludes other citizen groups. ${ }^{18}$

As more and more modern urbanists and architects admit, in the future smart and sustainable urban planning should concentrate neither on new ideal models, nor on praising the informality. Rahoul Mehrotry proposes a loose metaphor of "The Kinetic City" that is based on a strong precognition that

15 For more on Mona Tusz's social projects, see: B. Stano, Muralistka (Mona Tusz) i fotograf (Arkadiusz Gola) wobec zjawisk negatywnych po restrukturyzacji gospodarczej na Ślasku, in: Studia de Arte et Educatione, 12/2017, pp. 129-149.

16 The most commented example of such attitude was revealed in a work "Lelki z Hugo", when the mural made on a wall tagged by Ruch Chorzów fans was intentionally designed to provoke reaction from the side of the local football hooligans. Then, the artist documented the process of her work being covered by hooligan graffiti. http://www.monatusz.art.pl/index. php?/ongoing/lelki-z-hugo/ accessed: 18 August 2018.

17 K. Lynch, The Image of the City, MIT Press, Cambridge, Massachusets, 1960.

18 P. Bourdieu, Language and Symbolic Power, Harvard University Press, 1991, p. 97. 
somatic aspects in urban planning matter, however, we should find the right balance between informal forms of embodied somatic perception and some level of objectivity. Otherwise, taking into account that modern conurbations have millions of citizens, urban life based just on promotion of informality (versus a dehumanized, traditional model of metropolis) is going to collapse sooner than later. Mehrotry perceives "The Kinetic City" as a sphere of dynamic dialog, in which art and rituals can play a role of medium between objectified and social sphere of urban life and private, embodied experience of its citizens. ${ }^{19}$ It seems the way of perceiving urban life practice is highly inspiring in the process of understanding modern street art practices, especially some sort of mural paintings appealing to haptic qualities.

\section{Somatic murals on Upper Silesia}

Not all murals exhibit haptic qualities. Many, maybe most of them are produced as a part of the modern visual culture and can be treated as a form of architectural tattoo applied onto buildings. However, with no doubts there also exists a specific class of mural paintings that affects haptic qualities of citizens' bodies and establishes temporary, local orders of perception. This process can be understood as dual, interactive, embodied relation between the painted structure and citizens. Describing the desire for street art to redefine the relation of citizens to the city, Halim Bensaid points out the fact that this should be always local - what matters is the relation to one's own city. ${ }^{20}$ This is, however, hardly to achieve only on a level of visual identification, as massive multiplication of symbols of identity produces an effect of anesthetization and emptiness. ${ }^{21}$ It is no wonder then that some local and resident artists try to reach further by appealing to psychosomatic bonds that tie citizens to their neighborhood. I will refer to three examples of such behavior now.

19 R. Mehrotry, The Kinetic City, interview, https://www.youtube.com/watch?v=wJFVXmZJop0 accessed: 17 August 2018. Mehrotry appeals to his experience of creating the Kumbh Mela temporary city. Kumbh Mela is a religious festival in India that lasts more than one month. During each edition the city hosts millions of pilgrims.

20 H. Bensaid, op cit, p. 156.

21 In Silesian context, this process is manifested through trivializaton of industrial motives, which are associated with the region identity. Multiplicity of products and images coming from the creative branch leads to a shallow narration based on a coal mining heritage, in area where almost all coal mines has been shut down two decades ago. 


\section{Black mural, Cleon Peterson}

Cleon Peterson, a renowned artist from Los Angeles, painted a mural on the wall of railway overpass on Francuska Street during his residency at Street Art Festival in Katowice. The mural features black humanoid creatures fighting one another with primitive tools. It is nothing unusual, as the artist very often multiplies and redefines the same visual theme worldwide. What is striking, however, is the context generated by the connection of the dark theme and the postindustrial neighborhood of the overpass. The idea of putting the artwork underground and using black to paint the bodies evoke associations with miners working in close vicinity of the place. This is strengthened by the fact that some other artworks placed earlier in parallel viaducts feature mining themes. However, the negative undertone of the mural creates a dissonance with the popular, idyllic narrative of workers' life in the "good old times" of prosperity in the region. The mural produces a certain type of somatic anxiety as passersby walk under the overpass surrounded by Peterson's aggressive figures. The experience is produced by the horizontal arrangement of space of the passage in which 3-meter-high figures dominate over pedestrians.

\section{Face tree mural, Raspazjan}

Raspazjan, a local artist, is the author of the "Face tree" mural, hidden in one of the backyards on 3 Maja Street in Katowice. The mural was a subject of the activity of other artists, which can be treated as exemplary in the context of somatic mural participation process. The vertical mural was animated by dancers during a special night-time event, which involved building mapping and choreography. The Zakorzenieni (The Rooted) project was based on the idea of redefining perception of the mural from the vertical to horizontal by creating an impression of dancers walking and dancing on the surface of the mural. Dancers then became part of the mural in a literal sense. This was also reinforced by the significance of the artwork depicting faces growing on a tree trunk and the name strongly appealing to the sense of locality: "rooted". ${ }^{22}$

\section{Postlaubizm project, mural series, Raspazjan}

The Postlaubizm project is a short series of murals created by Raspazjan on the walls of abandoned small recreation houses standing in R.O.D. gar-

22 “Zakorzeni” https://www.youtube.com/watch?time_continue=107\&v=iH-XSzbUq18 [accessed 27 August 2018]. 
dens. ${ }^{23}$ Those abstract murals are placed on devastated and probably forgotten buildings, thus creating a strong contrast between the vanishing structures of the houses and the perfect contour of the colorful paintings. The name of the project is a derivate of the Silesian word lauba, which means a small recreation hut, built in a rather informal style, similar to Norwegian hytte. The idea of repainting laubas appeals to the sense of loosing the old school, good way of life in a direct, somatic contact with urban nature, which is now becoming forgotten. ${ }^{24}$ It is striking that one of the murals, called "Anxiety" and meant as a glimpse into an imagined interior of a hut, confronts passers-by with a sad face of its inhabitant.

Two of the three described murals have been officially commissioned, while the last one was illegal. It is worth to mention that regardless of the involvement of institutional support or the lack thereof, the practice remained the same: a strong focus on psychosomatic interaction with citizens. Murals that manifest strong somatic aspects are definitely rare, however, if street art is meant to still mean something in the city, this is where its future lies.

\section{BIBLIOGRAPHY}

Bensaid Halim (2016) Mural Painting and The Spirit of The Place Versus Graffiti and Stret Art, in: A. Gralińska-Toborek, W. Kazimierska-Jerzyk ed, Aesthetic Energy of the City. Experiencing Urban Art \& Space, Łódź: WUŁ.

Berleant Arnold (2005) Aesthetics and Environment. Theme and Variations on Art and Culture, Aldershot - Burlington: Ashgate.

Bourdieu Pierre (1991) Language and Symbolic Power, Harvard University Press.

Gehl Jan (2017) Zmysty i skala, in: Miasta dla Ludzi, Kraków.

Gralińska-Toborek Agnieszka (2016) Street Art and Space, in: ed. A. Gralińska-Toborek, W. Kazimierska-Jerzyk, Aesthetic Energy of the City. Experiencing Urban Art \& Space, Łódź: WUŁ.

Hall Edward (1973) The Silent Language, New York.

Hall Edward (1990) The Hidden Dimension, New York.

Lynch Kevin (1960) The Image of the City, Cambridge, Massachusets: MIT Press.

23 R.O.D. - Rodzinne Ogródki Działkowe, family gardens recreation system, originally from the communist era, still popular nowadays.

24 Raspazjan, Postlaubizm, Anxiety mural http://raspazjan.blogspot.com/2016/01/anxiety. html [accesed 27.08.2018]. 
Łukaszewicza - Alcaraz (2016) Street-art, graffiti, wandalizm - w kontekście estetyki środowiskowej Arnolda Berleanta, in: M. Baranowski, P. Cichocki, Przestrzeń publiczna i państwo dobrobytu, Poznań: UAM.

Mirzoeff Nicolas (1999) An Introduction to Visual Culture, Routledge, London and New York.

Pallasmaa Juhani (2011) Krajobrazy Zmystów. Dotykanie świata przez architekturę, in: "Autoportret” $3[35]$.

Petri Jakub (2016) Body Consciousness in Urban Surrounding: Freerunning and Parkour, in: A. Gralińska-Toborek, W. Kazimierska-Jerzyk ed, Aesthetic Energy of the City. Experiencing Urban Art \& Space, Łódź: WUŁ.

Petri Jakub (2015) The Artistic Turn in Graffiti Practice: Szwedzki vs Mona Tusz, "Art Inquiry. Recherches sur les art”, XVII (XVI).

Stano Bernadetta (2017) Muralistka (Mona Tusz) i fotograf (Arkadiusz Gola) wobec zjawisk negatywnych po restrukturyzacji gospodarczej na Ślasku, in: "Studia de Arte et Educatione" 12.

\section{MURALE JAKO MEDIUM UCIELEŚNIONEJ PARTYCYPACJI W PRZESTRZENI MIEJSKIEJ (streszczenie)}

Artykuł odnosi się do somatycznych aspektów street artu, w szczególności murali. Murale zaprezentowane zostają jak źródło polisensorycznego doświadczenia estetycznego mieszkańców oraz jako medium miejskiej partycypacji. Street rozumiany jest tutaj jako konstytuująca się oddolnie i organicznie przestrzeń dialogu pomiędzy zobiektywizowanymi zakresami społecznego życia w mieście a prywatną, ucieleśnioną sferą doświadczenia estetycznego mieszkańców.

Słowa klucze: murale, miejskość, partycypacja, zmysł haptyczny, wizualność 


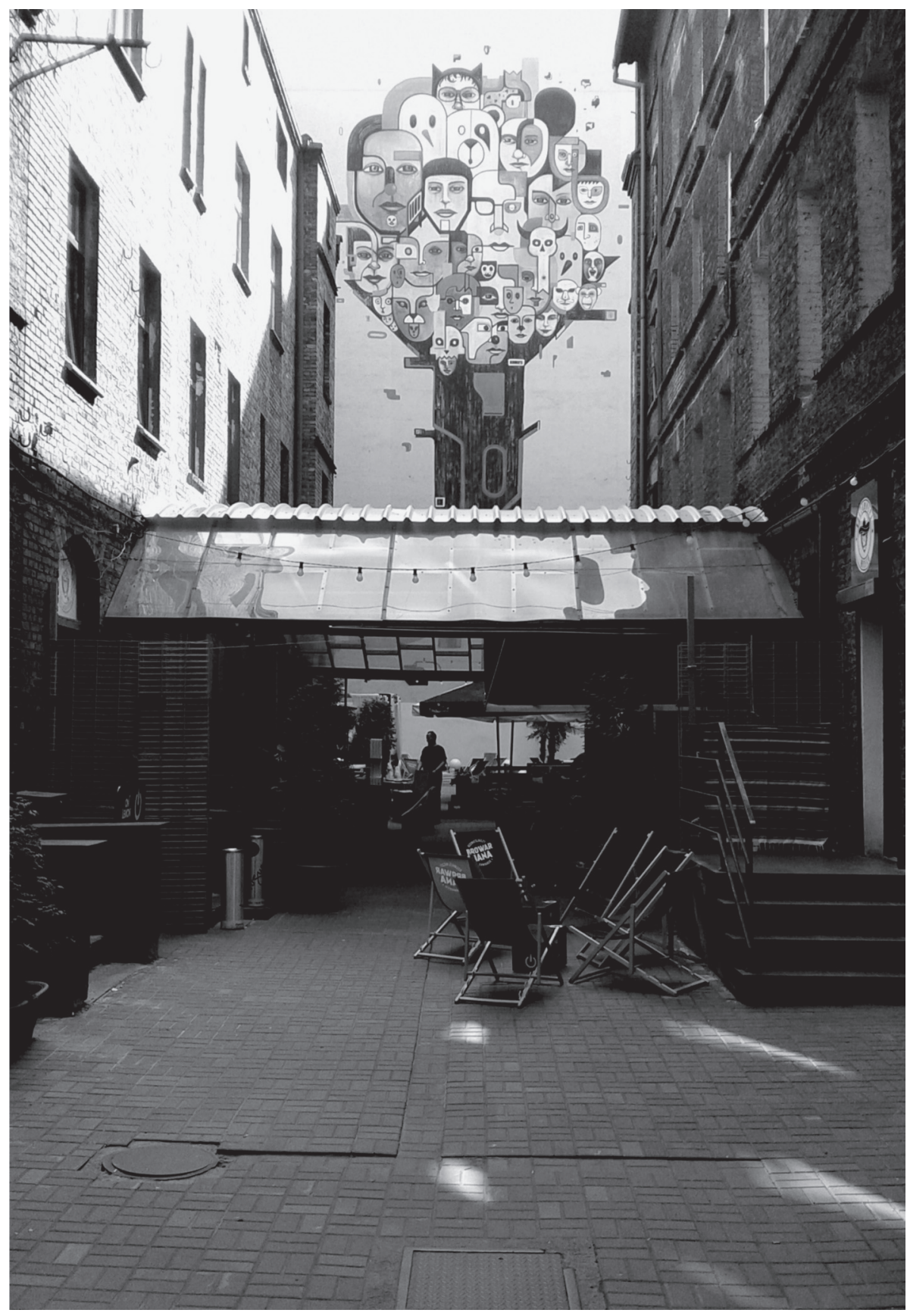

1. Face Tree mural, Artist: Raspazjan, 3 Maja street 38, Katowice 


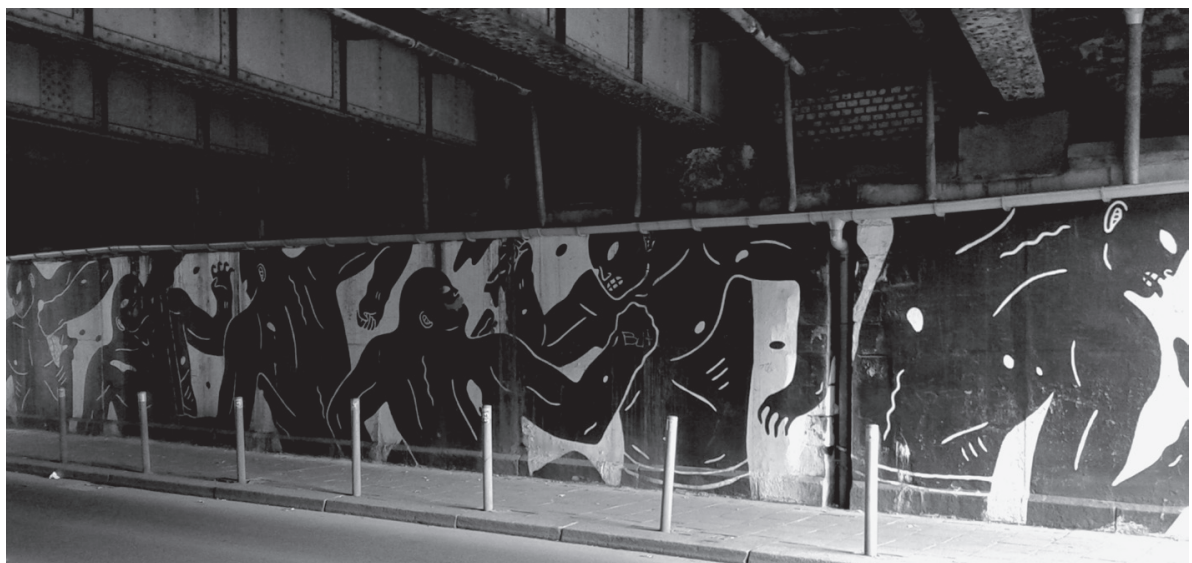

2. Black mural, Artist: Cleon Peterson, Francuska street - viaduct, Katowice

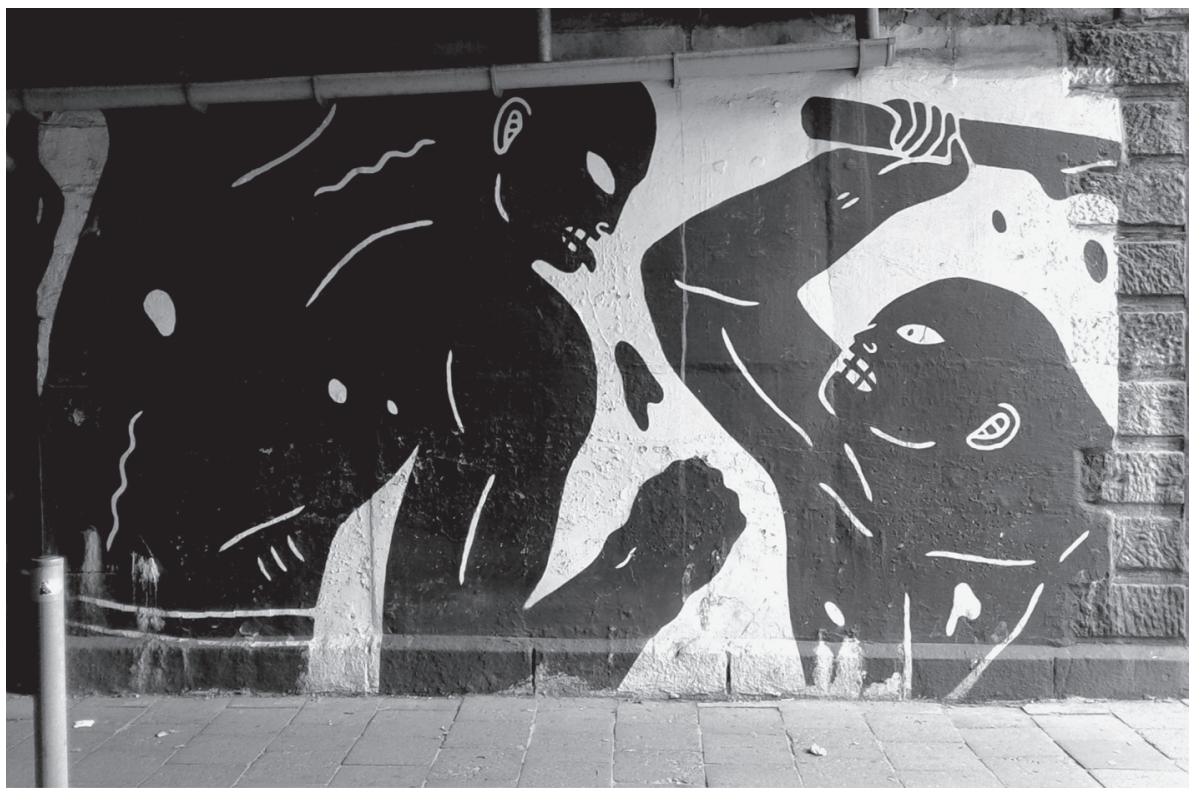

3. Black mural, Artist Cleon Peterson, detail 